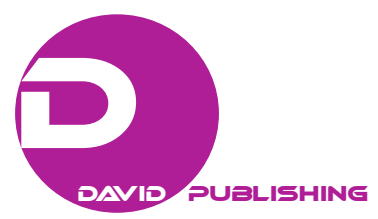

\title{
Structural Development of Oxford Advanced Learners’ Dictionary
}

\author{
Ivana Ivančič, Ivo Fabijanić \\ University of Zadar, Zadar, Croatia
}

\begin{abstract}
Oxford Advanced Learners' Dictionary (OALD) stands out, on the EFL market, as the only EFL dictionary which has been continuously republished for over 70 years. With each new edition upgraded, OALD conforms to the contemporary language teaching and learning processes worldwide. This article presents its structural development - an evolution from its very first, Japanese edition in 1942 towards the latest one in 2015. The analysis deals with the development and changes within the macrostructural (front matter, the body, appendices) and microstructural (headword, spelling, pronunciation, part of speech, senses, definitions, illustrations, usage) frames of the dictionary.
\end{abstract}

Keywords: macrostructure, microstructure, verb-patterns, OALD

\section{Introduction}

With development of science and technology, education and knowledge of foreign languages have become extremely important. Increased foreign language learners' needs have led to the cooperation of language teachers and dictionary compilers, which has resulted in certain observations that have set the stage for the development of a special foreign language learner dictionary ${ }^{1}$, which was first published during the $1930 \mathrm{~s}^{2}$. "Equipped" with special additions, such a dictionary has had a considerable educational role in learning a foreign language since it enables the learners to improve their knowledge and language skills. As the greatest novelty of the 20th century, EFL dictionaries have made a significant contribution to English lexicography the more so their development does not stagnate.

Owing to the longest tradition on the EFL market, which lasts about as much as the genre, Oxford Advanced Learners' Dictionary has been the first serious contributor to the genre. Today, the OALD's editors carefully supervise and examine EFL learners' lexicographically relevant needs and according to them upgrade the dictionary's macro- and micro-structural elements. The following (sub)chapters deal with the elaboration of the OALD's macro- and micro-structural elements throughout its development.

Ivana Ivančič, Independent Researcher, MA, Zaprešić, Croatia.

Ivo Fabijanić, Ph.D., Assistant Professor, University of Zadar, Zadar, Croatia.

${ }^{1}$ More about the structure of EFL dictionaries in: Fuertes-Olivera, P. A., \& Tarp, S. (2011), "Lexicography for the third millennium: Cognitive oriented specialized dictionaries for learners"; Włodarczyk-Stachurska, A. (2012), "Some Remarks on Recent Trends in Lexicography".

2 More about the history of the EFL lexicography in: Cowie, A. P. (2009), "The Earliest Foreign Learners' Dictionaries"; McArthur, T. (1989), "The Background and Nature of ELT Learners' Dictionaries". 


\section{A Brief History of OALD}

Oxford Advanced Learner's Dictionary is the first EFL dictionary aimed at more competent i.e. advanced foreign learner. Since its very first publication in Japan in 1942, under the title Idiomatic and Syntactic English Dictionary (ISED), the dictionary has been republished nine times by Oxford University Press under the title Advanced Learners' Dictionary (ALD) / Oxford Advanced Learners' Dictionary (OALD). Behind the dictionary's creation is a fascinating story of a "simple teacher" whose passion for language teaching changed the way the world learns English.

Albert Sydney Hornby, the author of OALD, was an English teacher in a small provincial college in Japan. He made language learning approachable by always using clear and understandable English. Hornby's interest in ordinary English words and phrases became almost obsessive. He would "hear and see things, make a note on a sheet of paper or a card, and drop it into a box" (The Man Who Made Dictionaries, 2015). He searched for the words from his daily life, the Shorter Oxford English Dictionary and Webster's Dictionary to collect information on the English language. In 1938, his scribbled notes describing English words and phrases began their transformation into the English Dictionary for Learners, which became the Idiomatic and Syntactic English Dictionary (The Man Who Made Dictionaries, 2015). The following year, Bombay offices of Oxford University Press (OUP) received a package of four drab little books full of Japanese notes sent by an unknown Japanese publisher, Kaitakusha. The books had been sent for review in OUP's Teaching Journal, but were of no interest to Indian teachers. However, the journal editor noticed an advertisement on the back cover-under the heading "in preparation" was a description of the forthcoming Idiomatic and Syntactic English Dictionary. A letter from Oxford University Press was sent to the Japanese publishers asking for sample pages to be sent immediately. This was the first indication of how important an international edition of this dictionary could be (The Man Who Made Dictionaries, 2015). Although Kaitakusha had already advertised Hornby's forthcoming ISED, getting it printed was not easy. In 1940, while Kaitakusha was trying to print the ISED in Japan, Hornby wanted to get a copy of the pages to OUP's headquarters in England so the international edition could be printed. The world was at war and getting 1,500 pages sent safely from Japan to London was risky. One set of dictionary pages was successfully sent via the Director of the British Library of Information and Culture in Tokyo, but the other set never made it to England and disappeared without a trace (The Man Who Made Dictionaries, 2015). After the bombing of Pearl Harbour in 1941, Hornby was held under house arrest in Japan until he was exchanged for Japanese prisoners. Instructed to take only clothes on his long voyage home, Hornby carefully hid his last set of dictionary pages in the bag and boarded a ship for England. ISED was published quietly in Japan in 1942, but Hornby, its creator, did not set eyes on it until after the war-in 1948. In England, publishing a dictionary was very difficult. Paper was in short supply and Oxford's Shakespeare and the Bible print runs were cut to provide extra paper. Finally, the first edition of A Learner's Dictionary of Current English was published in 1948. In the first 15 months of its life, it sold 10000 copies and went on to become OUP's biggest-selling title of all time (The Man Who Made Dictionaries, 2015). In 1952, Oxford changed the title to The Advanced Learner's Dictionary of Current English, whereas from the third edition onwards The was omitted, and it is now known by the title Oxford Advanced Learners' Dictionary (OALD) (Jackson, 2002, p. 129).

Hornby has had a profound influence on English Language Teaching, not only through his publications 
and ideas on teaching method ${ }^{3}$ but also through the A. S. Hornby Educational Trust, set up in 1961. This was a generous initiative whereby a large proportion of Hornby's income was set aside to improve the teaching and learning of English as a foreign language, chiefly by the provision of grants to enable teachers of English from overseas to come to Britain for professional training (The Man Who Made Dictionaries, 2015). Thanks to the Trust, hundreds of teachers have been able to develop their expertise through British Council Summer Schools and post-graduate courses in linguistics and ELT at British universities (A. S. Hornby Educational Trust, n.d.).

\section{Methodology}

The aim of the paper is to determine OALD's structural changes which occurred during its chronological development. Therefore, the main tasks are:

- to present the macro- and micro-structural elements of each OALD's edition as well as;

- to compare their similarities and differences.

All the information, which has been presented in one of the following forms: (1) textual, (2) tabular, (3) visual, or (4) diagrammatic form, has been explained. Where necessary, conclusions and comments, based on the comparison of presented information, have been corroborated by additional secondary sources.

Table 1

Years of Publication, Publishers and Principal Editors of Each OALD Edition

\begin{tabular}{llll}
\hline $\begin{array}{l}\text { OALD } \\
\text { edition }\end{array}$ & $\begin{array}{l}\text { Year of } \\
\text { publication }\end{array}$ & Publisher & Principal editor(s) \\
\hline ISED & 1942 & Kaitakusha & A. S. Hornby, E. V. Gatenby, A. H. Wakefield \\
ALD1 & 1948 & Oxford University Press & A. S. Hornby, E. V. Gatenby, A. H. Wakefield \\
ALD2 & 1963 & Oxford University Press & A. S. Hornby, A. P. Cowie, A. C. Gimson \\
OALD3 & 1974 & Oxford University Press & A. P. Cowie \\
OALD4 & 1989 & Oxford University Press & J. Crowther \\
OALD5 & 1995 & Oxford University Press & S. Wehmeier \\
OALD6 & 2000 & Oxford University Press & S. Wehmeier \\
OALD7 & 2005 & Oxford University Press & J. Turnbull \\
OALD8 & 2010 & Oxford University Press & M. Deuter, J. Bradbery, J. Turnbull \\
OALD9 & 2015 & &
\end{tabular}

Lexicographical units used in the analysis, have included the first edition Idiomatic and Syntactic English Dictionary (ISED) published by Kaitakusha and all the remaining ones (2nd-9th) published by Oxford University Press. In terms of the years of publication, it can be noticed that OALD's early editions were published in irregular intervals (interval $=$ the period, measured in years, between the two editions' publications). For instance, the period between 1948, when ALD1 was published, and 1963, when ALD2 was published, presents the interval of 15 years which had to pass for the second edition to be published. After the publication of ALD2, the users of the dictionary had to wait 11 years for the third edition to be published, and another 15 years for OALD4. OALD5 was in preparation for a relatively short period of time -6 years, with regard to its preceding editions. The following editions (OALD6-9) were published in regular intervals of 5 years. Since each of the first few editions (ALD2-OALD4) took between 10 and 15 years to be published, it can be concluded that they were in preparation twice or three times longer than the editions published after 1995 (OALD6-9), each of which took 5 years to be published.

\footnotetext{
3 More about Hornby's professional career in: Cowie, A. P. (1998), “A. S. Hornby-A Centenary Tribute”; Cowie, A. P. (1999), English Dictionaries for Foreign Learners-A History.
} 


\section{Analysis}

\section{Macrostructure}

During OALD's development, its macrostructure has been continually changing and upgrading. Some new elements have been included, whereas some other excluded. The following subchapters elaborate development of OALD's macrostructure - front matter, the body of the dictionary, and appendices.

Front matter. Segments of OALD's front matter differ from edition to edition (Table 2), but some are common to all of them or at least to the majority. Namely these are: Preface/Foreword, Guide on using the dictionary, Key to dictionary entries, and Abbreviations.

Table 2

Contents of OALD's Front Matter

\begin{tabular}{lllllllllll}
\hline Section & \multicolumn{1}{c}{ OALD's edition } & \multicolumn{1}{c}{} \\
\cline { 2 - 9 } & 1 & 2 & 3 & 4 & 5 & 6 & 7 & 8 & 9 \\
\hline Preface/Foreword & + & + & + & + & + & + & + & + & + \\
Using the dictionary & + & + & + & + & + & - & - & - & - \\
Key to (dictionary) entries & - & - & + & + & + & + & + & + & + & + \\
Abbreviations & + & + & + & + & + & + & + & + & + \\
Symbols & - & - & - & - & + & + & + & + & + \\
Labels & - & - & - & - & + & + & + & + & + \\
Numbers & - & - & - & - & - & + & + & + & + \\
Phonetic symbols & + & + & + & + & - & - & - & - & - \\
Key to verb patterns & - & - & - & - & - & + & + & - & - \\
Understanding definitions & - & - & - & - & - & + & - & - & - \\
\hline
\end{tabular}

Notes. + included, - excluded.

The Preface/Foreword and list of Abbreviations are the two front matter sections which are shared by all the editions. Other sections which are most frequently included are: Guide on using the dictionary (ISED/ALD1-OALD5), Key to dictionary entries (OALD3-9) and lists of Symbols and Labels (OALD5-9).

Preface/Foreword. The aim of the preface is to introduce dictionary users to each new, revised and re-set edition. Besides information about new macro- and micro-structural features, which are common to the prefaces of all editions, there is certain information which differs the contents of the prefaces. For instance, in ISED, ALD2 and OALD3 there is information about the type of the target audience-learners and teachers of EFL.

Since Hornby died shortly after the emergence of OALD3, chief editors of the following editions have been continuously changing. They make lists of acknowledgements by mentioning all the co-operators and contributors who helped in OALD's development. Also, some of them emphasize the importance of the resources which the dictionary has been based on (see Table 3 ).

Table 3

The Sources of OALD Editions

\begin{tabular}{ll}
\hline Edition & Source(s) \\
\hline OALD4 & $\begin{array}{l}\text { Four-year Programme of basic research carried out by the OUP Lexical Research Unit at the University of Leeds, } \\
\text { the OED archive }\end{array}$ \\
OALD5, 6 & $\begin{array}{l}\text { The British National Corpus } \\
\text { OALD7 }\end{array}$ \\
The British National Corpus, the Oxford Corpus Collection, the Oxford Reading Programme for language research \\
OALD9 & $\begin{array}{l}\text { The British National Corpus, the Oxford English Corpus } \\
\text { Oxford English Corpus }\end{array}$ \\
\hline
\end{tabular}


The majority of OALD's editions (OALD4-9) used linguistic corpora to improve their contents. The others like ISED, ALD2 and OALD3 were compiled in the period of pre-corpus linguistics when linguistic corpora did not exist and when all the lexical data stored in the dictionary had to be gathered manually. Corpus linguistics made a huge impact in overall dictionary-making process - from the reduction of time necessary to compile a dictionary to the higher capacity of the word storage.

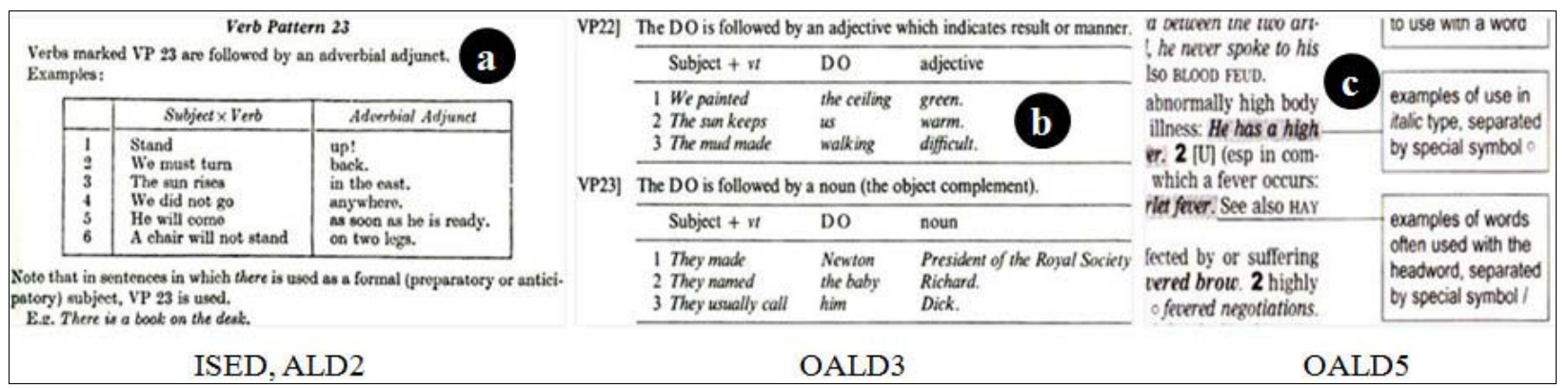

Figure 1. Fragments of Guide on using the dictionary (ISED, ALD2, OALD3) and Key to dictionary entries (OALD5).

Using the dictionary. The guides of ISED and ALD2 begin with printing conventions of dictionary's microstructural elements. They continue with Notes on Syntax and end up with a specially designed scheme of verb patterns (Figure 1a), which is characteristic of OALD's early editions. The guide of OALD3 contains sections-Finding words and meanings, Writing English, Speaking English, Grammar, and Style, which include printing conventions as well as definitions and instructions on their usage. Detailed information on verb patterns in a tabular form is also included in the guide (Figure 1b). The guide of OALD4 does not try to provide a full explanation of the given information or their arrangement, since detailed guide can be found in the appendices. OALD5 is the last edition in which the user can read the guide in the front matter- the editions which followed included all those information within the study pages or appendices.

Key to entries. Key to entries depicts fragments from the body (entries) and labels all the microstructural elements (Figure 1c). In this way it instructs the learners about the microstructural information that can be searched for and read when consulting the dictionary.

Abbreviations, symbols and labels. Abbreviations, symbols and labels presented in lists, clarify what all abbreviations, symbols and labels, used in the dictionary, mean.

Phonetic symbols. In earlier editions, the section appears in the front matter, whereas later editions include it in their appendices.

The body. The body of OALD contains a list of headwords accompanied by blocks of information, which together with headwords constitute "entries". Throughout OALD's chronological development, certain body features have remained unchanged, whereas some segments have undergone more or less perceptible changes. The only feature which has been retained from the first edition is the setting of the vocabulary list. Alphabetically arranged, the list is presented in two columns on each page with its headwords printed in bold type and hanged a bit to the left from the other lines. Alongside this feature, shared by all the editions, changes in body development have been slightly more numerous. They are connected with: (1) the body extent measured by the total page amount, (2) the quantity of the word-stock, (3) additional materials incorporated into the vocabulary list, and (4) graphical organization of header and footer.

The body extent measured by the total page amount. The rise and fall of the total body page amount 
influence the changes of the body extent — the more page number there is, the larger the body extent is, and vice versa.

Table 4

Total Page Amount According to Edition

\begin{tabular}{|c|c|c|c|c|c|c|c|c|}
\hline ISED & ALD2 & OALD3 & OALD4 & OALD5 & OALD6 & OALD7 & OALD8 & OALD9 \\
\hline 1283 & 1170 & 1003 & 1492 & 1392 & 1539 & 1780 & 1796 & 1820 \\
\hline
\end{tabular}

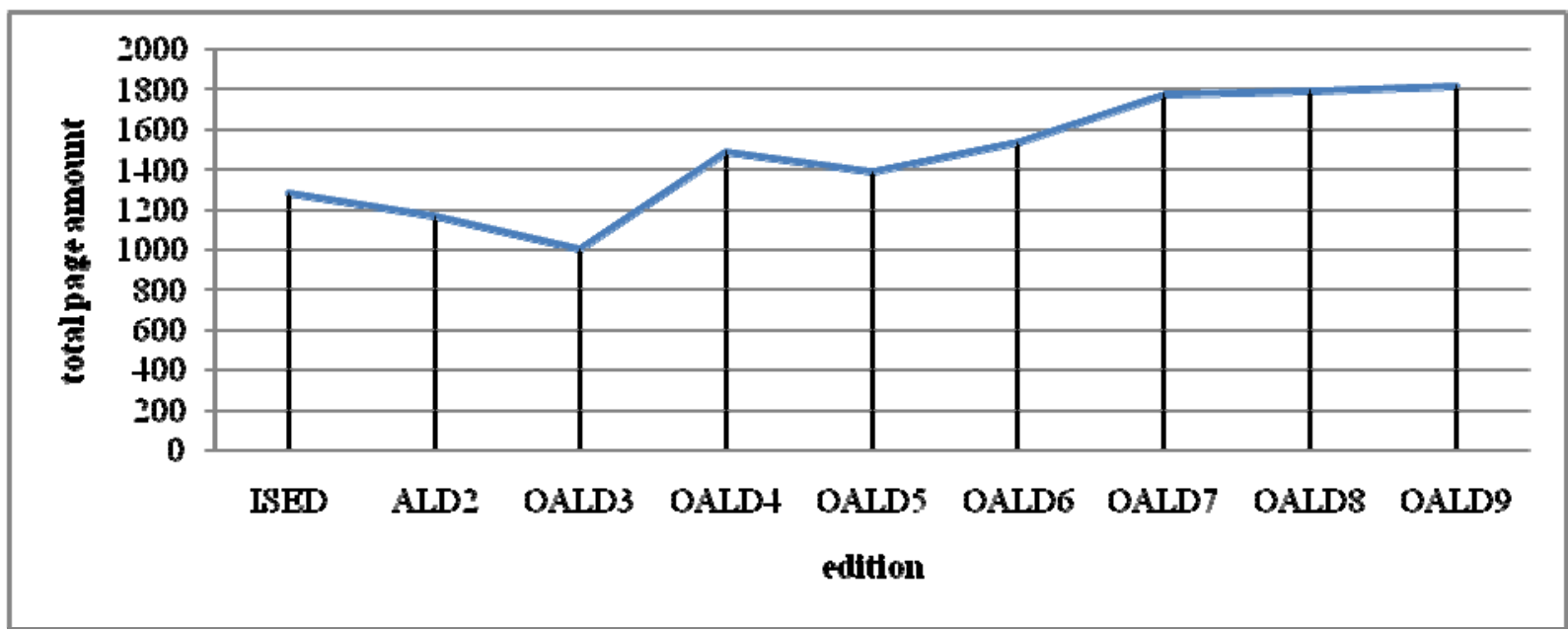

Figure 2. Oscillations of the total page amount.

If we take a look at the Table 4, which presents the data on the body's total page amount of each OALD's edition, it can be clearly noticed that the number varies. According to the data, it may be observed that the rise of the body total page amount has affected five out of nine OALD's editions (OALD4, 6-9). The most significant change has occurred with the fourth edition, in which the total page amount has been increased for almost 500 pages with regard to its previous edition. Besides the multiple growth, OALD's body has faced the fall of the total page amount three times (ALD2, OALD3, 5). Irregular oscillations of the total page amount prove that both, the enlargements and reductions of the body extent have been present during dictionary's development.

Table 5

The Change of Total Page Amount of Each Edition in Regard to ISED (in \%)

\begin{tabular}{llllllll}
\hline ALD2 & OALD3 & OALD4 & OALD5 & OALD6 & OALD7 & OALD8 & OALD9 \\
\hline$-8,80$ & $-21,82$ & 16,28 & 8,49 & 19,95 & 38,73 & 39,98 & 41,85 \\
\hline
\end{tabular}

When comparing the total page amount of each edition with ISED (see Table 5), it can be noticed that only two editions (ALD2 and OALD3) had less total page amount, while the rest ones (OALD4-9) counted more pages. OALD5 is the edition with the least difference of the total page amount $(8,49 \%)$ between the editions, whereas OALD9 is the one with the greatest difference $(41,85 \%)$ between the two.

The quantity of the word-stock. When dealing with the body extent, it has been determined that the overall quantity of the word-stock is closely related to it. Also, it has been affirmed that with each new edition, OALD's word-stock quantity has been changed. Table 6 presents more precise information on the word-stock quantity included in the dictionary, claimed by the OALD itself on the back covers of each edition. 
Table 6

OALD's Word-Stock Quantity According to the Edition

\begin{tabular}{llllllll}
\hline Edition & OALD3 & OALD4 & OALD5 & OALD6 & OALD7 & OALD8 & OALD9 \\
\hline Total amount of words & 50000 & 57100 & - & - & 183500 & 184500 & over 185000 \\
Amount of new words & - & - & 2800 & 4500 & 2000 & 1000 & $700+$ \\
\hline
\end{tabular}

Table 6 does not include numerical data for ISED and ALD2 since the two editions do not come out with any information about the word-stock quantity neither in their front matters nor their back covers. Also, the fifth and sixth editions do not contain the exact information about their word-stock quantity, but point out the data on the quantity of new words and phrases which have been included in their bodies with regard to their previous editions. Word-stock quantity of OALD4 has been increased for approximately 7000 new words in comparison with OALD3, which has been the greatest body enlargement in OALD's development. Since the data from Table 4 tell us that the body of OALD5 was reduced, the 2800 new words have not just been added to the vocabulary list of OALD4, but a good amount of words was removed from the list so that the word-stock quantity of the OALD5 declined. The case with OALD6 is different. The 4500 new words which entered the vocabulary list made the body of the sixth edition to grow simply because much more words were added to the list than excluded from it. The information on the word-stock quantity concerning OALD7, OALD8, and OALD9 indicate that they count the greatest amount of words, in relation to all the previous editions.

Additional materials incorporated into the vocabulary list. Additional materials which are incorporated into the vocabulary list have been upgraded during the OALD's development. Generally, they may be divided into three groups: illustrations, special paragraphs and study pages.

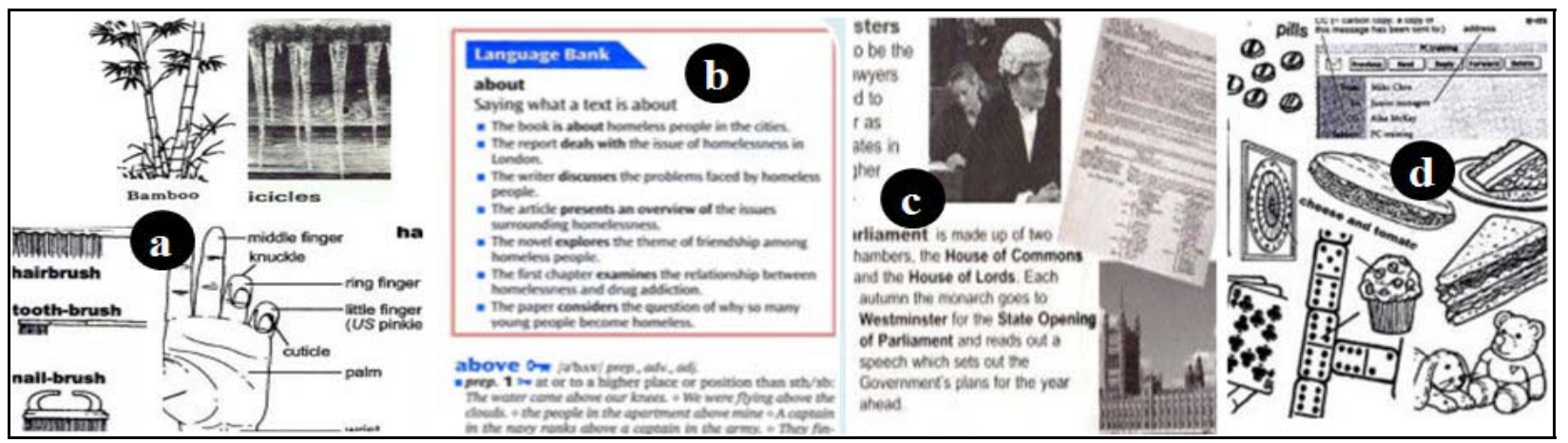

Figure 3. Fragments of illustrations, special paragraphs, and study pages.

(1) Illustrations. There are different kinds of illustrations which are presented as: 1) a single illustration, 2) a group of illustrations put under particular lexical subjects or themes such as tools, insects, vegetables, etc., and 3) illustrations depicting labelling of individual parts, for instance at vehicles, human body, domestic animals, etc. (Figure 2a). Illustrations, which are incorporated into the body of each OALD's edition, increase the educational role of vocabulary items.

(2) Special paragraphs. Special paragraphs are short notes on various aspects of usage in English. When first appeared, as notes on usage in OALD4, they included information explaining the differences between similar words and phrases. With each new edition, the paragraphs have been upgraded and their variety on aspects of language usage has been expanded. OALD6 introduced five new types of paragraphs: Vocabulary building, More about, Which word?, British/American, and Grammar point. OALD7 and OALD8 keep all the variety of the paragraphs from OALD6 and add four new ones: Synonyms, Collocations, Word family, and 
Language Bank (Figure 2b), whereas OALD9 keeps all the categories of paragraphs from the previous two editions and adds two new ones: Express yourself notes, and Word finder notes.

(3) Study pages. Sets of special study pages, incorporated into the bodies of OALD5 and OALD6, interrupt every 400-500 pages of their vocabulary lists. Although not much, their contents differ. OALD5 and OALD6 both contain language study pages which include basic grammatical terminology (Linking words together, Collocation, Nouns and adjectives, Verbs, Phrasal verbs, Idioms) and a brief guide on their usage. In OALD6 the section additionally includes the subchapters on writing (Informal letters, faxes, memos and e-mails, Formal letters, Writing a CV or resumé) which help learners in developing writing skills by providing useful examples and tips. Another section shared by both editions, contains pages of geographical maps which complement the cultural pages of OALD5 very well. Pages concerning cultural information (Figure 3c), in OALD5, make EFL learners familiar with important historical and political facts about The Commonwealth, UK and US constitution and government, Legal systems in England, Wales and the US, and The vocabulary of English. Besides language study pages and maps, OALD6 brings in the Topic and Illustrations pages which include a variety of visual materials on certain lexical subjects or themes such as Computing, Cooking, Health, Clothes and fabrics, Games and toys, etc. (Figure 2d). OALD7, 8 and 9 do not contain study pages incorporated into their bodies - such pages have become a part of their appendices.

Graphical organization of header and footer. The header of each edition consists of initial and final headword and a page number. Although the header content has not been changed throughout OALD's development, its graphical organization has been changed three times:

\begin{tabular}{|c|c|c|}
\hline give . & 524 & glamour \\
\hline gunner/gyroscope & 384 & \\
\hline borderland & 126 & \\
\hline
\end{tabular}

Figure 4. Examples of three header types.

(1) Header type 1 includes two headwords on each page, one of which is placed in the left and the other in the right corner with the page number in the middle. Header type 1 can be found in ISED, ALD2 and OALD4.

(2) Header type 2 includes two headwords on each page, both of which are placed either in the left-hand corner (left pages) or right-hand corner (right pages) divided by a slash (/). The page number is put in the top centre of each page. Header type 2 can be found in OALD3.

(3) Header type 3 includes one headword on each page placed either in its left-hand corner (left pages) or right-hand corner (right pages). The page number is put in the top centre of each page. Header type 3 can be found in OALD5, OALD6, OALD7, OALD8, and OALD9.

On the other hand, the contents of the footer have been changed only twice:

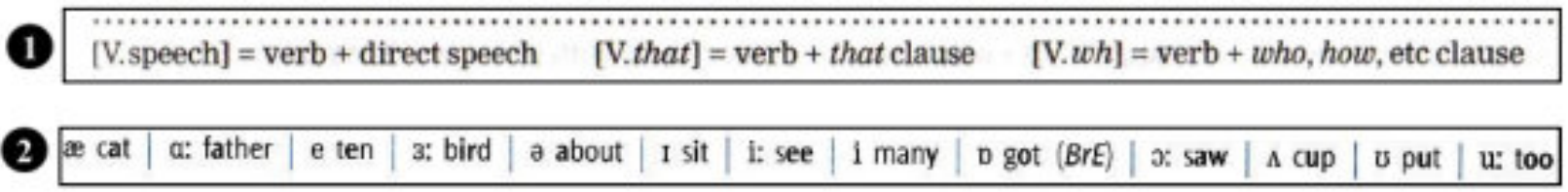

Figure 5. Examples of two footer types. 
(1) Footer type 1 contains information about verb codes (on each page) used in the dictionary. OALD5 is the only edition which includes footer type 1 .

(2) Footer type 2 contains information about phonetic symbols (on each page). This type of footer can be found in OALD7, OALD8, and OALD9.

Footers of ISED, ALD2, OALD3, OALD4 and OALD6 are empty i.e. do not include any information.

Appendices. The last macrostructural part of OALD - appendix, has been also continuously upgraded according to increasing learners' needs (see Table 7). It includes useful information, e.g. irregular verbs, colour topic pages, writing tutor, etc., which complement the other two major dictionary parts.

Table 7

Contents of OALD's Appendices

\begin{tabular}{|c|c|c|c|c|c|c|c|c|c|}
\hline \multirow{2}{*}{ Section } & \multicolumn{9}{|c|}{ OALD's edition } \\
\hline & 1 & 2 & 3 & 4 & 5 & 6 & 7 & 8 & 9 \\
\hline Irregular verbs & + & + & + & + & + & + & - & - & - \\
\hline Sport & + & + & - & - & - & - & - & - & - \\
\hline Music & + & + & - & - & - & - & - & - & - \\
\hline Commonly used abbreviations & - & + & + & - & - & - & - & - & - \\
\hline Measures, weights, etc. & - & + & + & + & - & - & - & - & - \\
\hline $\begin{array}{l}\text { Ranks in the armed forces } \\
\text { Ranks in the merchant marine } \\
\text { Full-rigged sailing ship }\end{array}$ & - & + & - & + & + & - & - & - & - \\
\hline $\begin{array}{l}\text { Sailing dinghy } \\
\text { Motor-car } \\
\text { Aeroplane }\end{array}$ & - & + & - & - & - & - & - & - & - \\
\hline Geographical names & - & + & + & + & - & + & - & - & - \\
\hline Books of the Bible & - & + & + & - & - & - & - & - & - \\
\hline Shakespeare's plays & - & + & + & - & - & - & - & - & - \\
\hline Common English Christian names & - & + & - & - & - & - & - & - & - \\
\hline Affixes & - & - & + & - & - & - & - & - & - \\
\hline Numerical expressions & - & - & + & + & + & + & - & - & - \\
\hline Common forenames & - & - & + & + & + & - & - & - & - \\
\hline Punctuation & - & - & + & + & + & + & - & - & - \\
\hline Chemical elements & - & - & + & + & + & - & - & - & - \\
\hline SI Units & - & - & + & + & + & - & - & - & - \\
\hline Family relationships & - & - & - & + & + & - & - & - & - \\
\hline Illustrations & - & - & - & + & - & - & - & - & - \\
\hline Notes on usage & - & - & - & - & + & + & - & - & - \\
\hline Defining vocabulary & - & - & - & - & + & + & - & - & - \\
\hline Phonetic symbols & - & - & - & - & + & + & - & - & - \\
\hline The language of literary criticism & - & - & - & - & - & + & - & - & - \\
\hline Oxford 3000 Vocabulary Trainer & - & - & - & - & - & - & + & - & - \\
\hline Maps & - & - & - & - & - & - & + & - & - \\
\hline Colour topic pages & - & - & - & - & - & - & + & - & - \\
\hline Reference section & - & - & - & - & - & - & + & + & + \\
\hline Oxford Writing Tutor & - & - & - & - & - & - & - & + & + \\
\hline Visual Vocabulary Builder & - & - & - & - & - & - & - & + & + \\
\hline Oxford Speaking Tutor & - & - & - & - & - & - & - & - & + \\
\hline
\end{tabular}

Notes. + included, - excluded. 
Despite the fact that ALD2-OALD5 count the most individual appendix sections, the last three editions (OALD7-9), which count the least, actually include the majority of the previous editions' sections within the three or four main sections. For example, the reference section, found in OALD7-9, includes subsections such as irregular verbs, geographical names, affixes, numerical expressions, punctuation, notes on usage, defining vocabulary, phonetic symbols, etc.

The list of irregular verbs is a crucial segment for grammar acquisition.

Sections music and sport contain illustrations of words used in music (the range of the human voice and of various musical instruments, key, rests) and sports (soccer, rugby, cricket). Their inclusion is due to enormous influence of Western music and games all over the world.

Section Commonly used abbreviations is a list of abbreviations which learners might come across either in language tasks or in everyday life.

Measures and weights section contains diagrams and conversion scales of European and American measuring systems.

Military ranks section lists military ranks in the Royal Navy, Army, Royal Air Force, and Merchant Marine.

Vehicles section includes drawings of vehicles (sailing ship, sailing dinghy, car, and aeroplane) with the labels.

Section Geographical names lists geographical names of world countries, well-known islands, oceans and seas, and English-speaking countries.

Section Books of the Bible lists the books divided into Old and New Testament.

Shakespeare's plays section provides a list of all Shakespeare's plays, whereas the section Common English Christian names the most popular English Christian names of the period.

Affixes section, divided into prefixes and suffixes, includes notes on how they are used in forming words as well as their pronunciation and examples of their usage.

Numerical expressions section represents a comprehensive guide on how to use numbers and expressions containing numbers, e.g. sports scores, time, distance, temperature, amounts of money, etc.

Section Common forenames lists all common forenames.

Punctuation section includes a detailed guide on how to use the punctuation marks and subsections Conversation, Quotation and Letters, which help the learners when dealing with the tasks of speaking and writing.

Section Chemical elements lists the names of all chemical elements and their abbreviations.

SI Units stands for the International system of units.

Section Illustrations contains a variety of visual materials sorted according to particular lexical fields or themes such as Flowering Plants, Breeds of Dog, Birds, Church, Theatre, Typical British Homes, Furniture, Motorway Intersection, and many more.

Section Notes on usage comprises a list of the entries at which the notes can be found and the words or language points covered at each.

Section Defining Vocabulary is a list of carefully chosen 3000 words used for defining vocabulary items found in the body of the dictionary.

The language of literary criticism is a section containing terminology concerning literary criticism followed by examples on usage, which helps EFL learners in the analysis of literary texts. 
Section Oxford 3000 Vocabulary Trainer is a set of working sheets which help learners to make better use of the dictionary, build on vocabulary they already know, write more fluently, and pass their exams.

Oxford Writing Tutor is a section in which learners can find examples on essays and practical types of writing that they can use as models for their own works. It also includes advice about planning, organizing and writing texts (different types of letters, essays, reports and reviews, summary, email, CV, oral presentations, discussions on pictures and cartoons, etc.).

Sections Maps and Colour topic pages are full of illustrative materials depicting maps of English-speaking countries and words sorted according to lexical fields (Vehicles, Buildings, Cooking, Houses, Health, The animal kingdom, etc.). In OALD8 and OALD9 these sections have been joined together and expanded into Visual Vocabulary Builder.

Reference section includes information on grammar, phonetic symbols, punctuation, Notes on Usage, Oxford 3000 defining vocabulary, list of proverbs, irregular verbs, short essays British and American English, English as a lingua franca, etc.

Oxford Speaking Tutor includes the subsections on preparations for speaking exams and oral presentations, learning how to converse in English, taking part in dialogues, etc.

\section{Microstructure}

OALD's microstructure has been more or less fixed from the first edition onwards. All the innovations have usually referred to more detailed and comprehensive, while at the same time less complex presentation of microstructural elements. The following subchapters present and compare OALD's microstructural elements and their changes.

Headwords and spelling. Headwords in OALD are printed in bold and hanged a bit to the left from the other lines. Types of headwords have not changed during OALD's development — all of them belong to one out of seven broader categories (OALD): letters, simple words, homographs, affixes, combining forms, abbreviations, and dummy entries (irregular forms of words).

Table 8

Types of Syllable Division

\begin{tabular}{lllllllll}
\hline \multicolumn{2}{l}{ OALD edition } & \multicolumn{1}{l}{} \\
\hline ISED & 2 & 3 & 4 & 5 & 6 & 7 & 8 & 9 \\
\hline- & space & $\cdot$ & $\cdot$ & no symbol & $\cdot$ & $\cdot$ & $\cdot$ & $\cdot$ \\
\hline
\end{tabular}

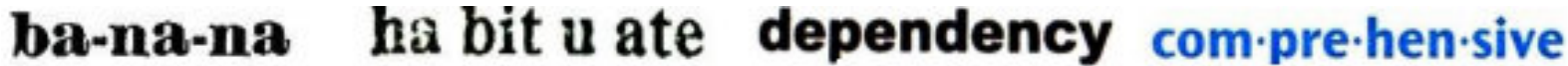 ISED \\ ALD2 OALD5}

Figure 6. Types of syllable division (examples).

Table 8 shows ways according to which headwords are divided into syllables in different editions. It may be noticed that, in the majority of editions, division of headwords into syllables has been presented by a dot $(\cdot)$, whereas in some editions-ISED and ALD2, it has been presented by a hyphen (-) or space. The division of headwords into syllables was not marked in the OALD5.

In every OALD's edition, headwords supply information about the spellings of words. Information about variations in spelling is also provided. The variation can be of various kinds. Some words have alternative spellings, both of which are equally acceptable: 


\section{cad die, cad dy kumis, kou.miss bougainvillaea (also bougainvillea) \\ ALD2 \\ OALD3 \\ OALD5 \\ Figure 7. Spelling variations (examples).}

OALD takes account of the differences between British and American spelling as well. In ISED and ALD2, American spellings have not been specially marked, whereas in the remaining editions they have-in OALD3, OALD4, and OALD5 as US; whereas from OALD6 onwards as AmE, or NAmE. British spellings are indicated by headwords, whereas American ones are added after them:

\section{the-a-tre, -ter ca.rou.sel (US car'rou-sel) edge.ways AmE edge-wise ISED OALD4 OALD6}

Figure 8. A display of British-American spelling (examples).

Pronunciation. The transcription system used to represent pronunciation, in OALD, is the International Phonetic Alphabet (IPA). The edition which stands out when it comes to the representation of phonetic notation is the third one. OALD3 went through two major phases (Stein, 1989, p. 23). Phonetic notation in OALD3 did not conform to Jones-Gimson system. Instead, it adopted a new transcription system developed by J. Windsor Lewis in his Concise Pronouncing Dictionary of British and American English only one year earlier. Teachers were upset by this because most of the textbooks and dictionaries, they used, followed the Jones-Gimson system. While the arguments for or against Lewis new notation, were still being debated, a new EFL dictionary was published: the Longman Dictionary of Contemporary English. In a short span of time the ALD had a serious competitor whose phonetic transcription mostly conformed to the English Pronouncing Dictionary. The publishers at Oxford University Press recognized the imminent danger and reacted. Not long after the publication of LDOCE1 they brought out a revised impression of the third edition of ALD in which the phonetic notation had been changed back to the Jones-Gimson system (Stein, 1989, p. 23).

In ISED and ALD2, each pronunciation, of each headword, is shown inside a pair of square brackets [ ], whereas in remaining editions (OALD3-9) it is shown inside a pair of forward-slashes / /.

\section{[,kæefi'tiorio]}

ALD2 /'ka:prt/

OALD4

Figure 9. Two display types of pronunciation (examples).

OALD records variation in pronunciation - it includes American pronunciation (marked by abbreviations U.S.A. in the first two editions, US in OALD3-6, and NAmE in OALD7-9).

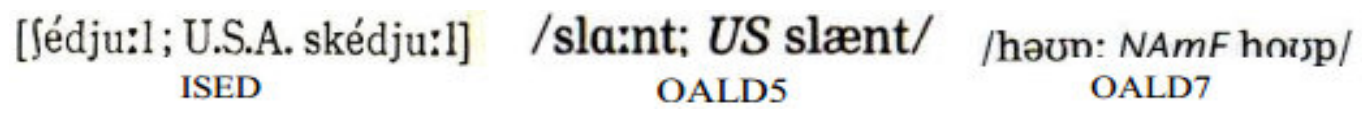

Figure 10. A display of British-American pronunciation (examples).

In ISED, a strong or primary stress is shown by the symbol ['] placed over the vowel, or the first element of the diphthong, in the syllable or syllables which receive this stress. A weak or secondary stress is shown by the symbol [']. In the remaining editions (ALD2-OALD9), the stress mark /l/ is used to show the strongest or primary stress, and $/ / /$ is used to show secondary stress. 


\section{[kònsəltéifən] [,bæsi'ende] /,edzu'kerJənl/ ISED \\ ALD2 \\ OALD6}

Figure 11. Stress symbols (examples).

Part of speech and inflections. OALD follows the lexicographic tradition in giving the grammatical information of each lexeme in the dictionary by using an abbreviated form for: nouns — n., adjectives—adj., pronouns - pron., verbs — v., adverbs - adv., prepositions - prep., and interjections - interj. Besides using standard part-of-speech abbreviations to indicate grammatical information, OALD's main objective had been to describe the syntactical behaviour of words. It focused firmly on the verb as the centre of the sentence. Hornby studied different syntactic possibilities of English very carefully and described them in types of construction - the famous verb patterns (VP) (Stein, 1989, p. 26). Having established which verb patterns to include, Hornby's problem was how to record the syntactic properties of individual dictionary entries in a concise yet informative way. His solution was "to encode this information at the point of entry, thus achieving economy, while at the same time providing an explicit tabular treatment in the Introduction, to which the codes could refer" (Cowie, 1983, p. 155).

\begin{tabular}{|c|c|c|c|}
\hline \multicolumn{4}{|c|}{$\begin{array}{l}\text { Verb Pattern } 9 \\
\text { Verbe marked VP } 0 \text { may be followed by an objet and a past participle. } \\
\text { Examples! }\end{array}$} \\
\hline & Sintject $\times$ Verb & Object & Past Participle \\
\hline $\begin{array}{l}1 \\
1 \\
3 \\
3 \\
4 \\
5 \\
6 \\
7\end{array}$ & $\begin{array}{l}\text { You must get } \\
\text { Whero did you have } \\
\text { ghe had } \\
\text { Have you ever heard } \\
\text { His ections made } \\
\text { King Charlen I had } \\
\text { The soldier had }\end{array}$ & $\begin{array}{l}\text { your hair } \\
\text { ithem } \\
\text { a new dreas } \\
\text { Italian } \\
\text { him } \\
\text { his head } \\
\text { two horsen }\end{array}$ & $\begin{array}{l}\text { eut. } \\
\text { peinted t } \\
\text { mede. } \\
\text { opoken ? } \\
\text { rewpected. } \\
\text { cut of. } \\
\text { shot under him. }\end{array}$ \\
\hline
\end{tabular}

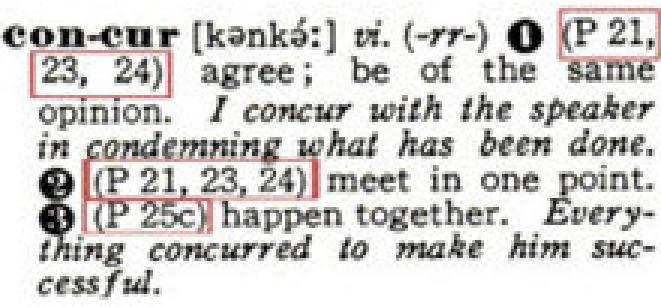

Figure 12. Fragments of ISED's verb patterns tabular scheme and an entry example.

By including the terms "idiomatic" and "syntactic" in the title of the first dictionary to be compiled for advanced learners, Hornby underlined his commitment to the encoding function (Cowie, 2009, p. 398). This commitment was strongly emphasized in the front matter of ISED, which was almost entirely taken up by the function words and verb patterns description (Cowie, 1998, p. 9). The most imposing part of the scheme is the presentation of 25 patterns with examples in a series of tables (Figure 12 left). The chief advantage of Hornby's tabular layout is that its vertical divisions (in columns), are made to correspond to the major structural elements of the pattern (Cowie, 1998, p. 10). In entries, verb patterns are displayed between the pronunciation information or sense number and a definition (Figure 12 right).

In ALD2, verb-pattern scheme and its presentation remained unchanged. Besides verb-patterns, there were other aspects of the total grammatical scheme that Hornby could, and did, deal with (Cowie, 2009, pp. 403-405). In the early 1950s, he produced some informative research on noun and adjective "complementation". This was published as part of A Guide to Patterns and Usage in English (1954), a small teaching grammar which included the results of an investigation into adjective-patterns and noun-patterns. In the Guide, Hornby referred to these categories by means of codes (e.g. NP2, AP1C, etc.) which were never incorporated in ALD2 itself (Cowie, 1998, p. 13). However, Hornby was able, thanks to this research, to improve on the coverage of noun + preposition collocations that he had already provided in the first edition. By 1963, patterns for all seventeen 
nouns were recorded, either by an example, or by means of a code, or as a part of the definition. ALD2 and 3 are sometimes criticized for failing to provide a systematic account of noun and adjective complementation (Cowie, 2009, p. 405).

\begin{tabular}{|c|c|c|c|}
\hline \multirow[t]{3}{*}{ VP21] } & \multicolumn{3}{|c|}{ The DO in followed by a newan (the otject eomptement). } \\
\hline & Subject + uf & Do & noun \\
\hline & 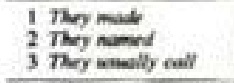 & $\begin{array}{l}\text { Nemnin } \\
\text { hite Aaty } \\
\text { him }\end{array}$ & 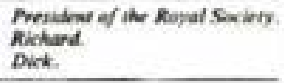 \\
\hline \multirow[t]{3}{*}{ vmen] } & \multicolumn{3}{|c|}{ The DO is followed by a peus participle. } \\
\hline & Subject $+\|$ & Do & past participle \\
\hline & 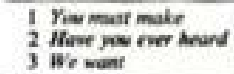 & 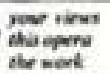 & 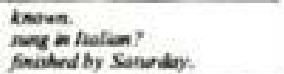 \\
\hline
\end{tabular}

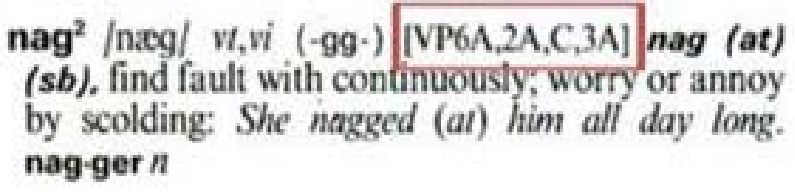

Figure 13. Fragments of OALD3's verb pattern tabular scheme and an entry example.

OALD3 includes the same number of verb-patterns (twenty-five) as in the previous two editions. However, the number of subdivisions was greatly increased-from thirteen to thirty-eight. The rearrangement of VPs according to their major verb-types owed much to the organization in the Grammar of Contemporary English (Cowie, 2009, pp. 406, 409). At times the reorganization of the VP scheme was unnecessarily detailed. The chief focus on criticism, however, was the letter-number codes, linking individual entries to the tabular scheme in the front matter (Figure 13 left). In entries, the codes were displayed in the same way as in ALD2 (Figure 13 right). The codes were simply an indication of where in the scheme a verb-pattern could be located (Cowie, 2009, p. 409).

Research into dictionary use has shown that foreign learners have had difficulties in handling grammatical codes (Stein, 1989, p. 27). Criticism of the grammatical codes, which appeared, was based on "the complexity of some coding systems and the often algebraic appearance of the symbols themselves, which is off-putting to many students, who in addition find the constant need to refer to explanatory tables time-consuming and irksome" (Cowie, 1983, p. 155). The solution might have been the introduction of standard abbreviations as NP (noun phrase), PreP (prepositional phrase), O (direct object), and so on. These class and clause element labels are already widely used in pedagogic grammars, and their introduction into EFL dictionaries would parallel the part-of-speech labels (n, adj, v, and so forth). The advantage of the use of familiar combinations such as $\mathrm{V}+\mathrm{O}$, $\mathrm{V}+$ Comp., is that "it has a mnemonic value, encouraging quick memorization of patterns and reducing the need for constant toing and froing between entries and illustrative tables and charts" (Cowie, 1983, p. 156).

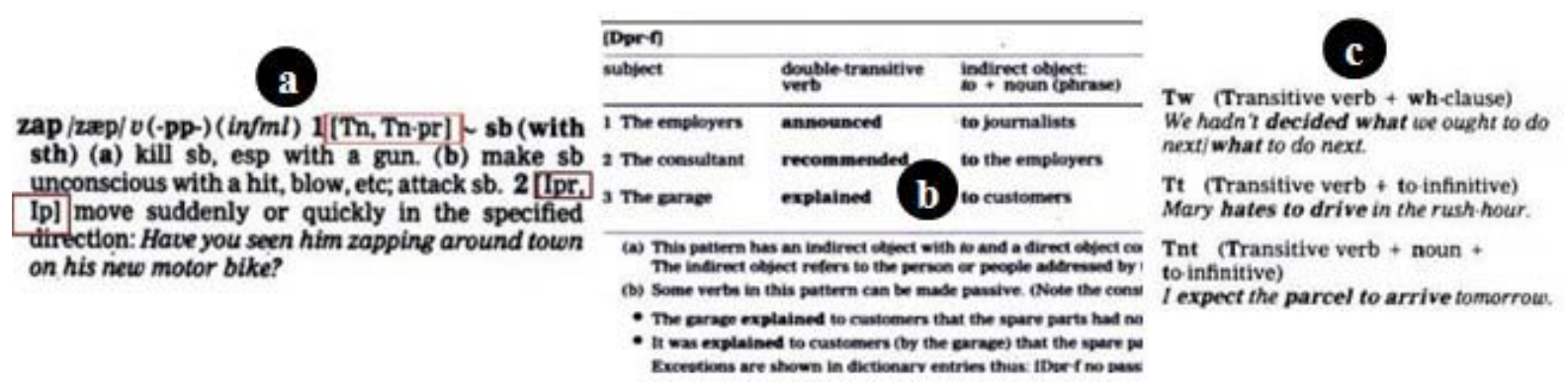

Figure 14. Fragments of OALD'4s entry, tabular scheme of VPs and the list of their abbreviated forms.

OALD4 retains tabular presentation of grammatical codes and patterns (Figure 14b), but replaces letter-number codes with abbreviated grammatical forms, listed at the very end of the appendices (Figure 14c). Verb-pattern codes in entries are placed immediately after the number introducing the sub-sense and before the 
definition (Figure 14a). Thirty-two patterns (with matching codes) are used in OALD4 to account for the various ways in which verbs can be used. Teachers especially should note that the codes can be read by the dictionary user on two levels: simple and structural (OALD4).

Verb classification scheme in OALD5 and 6 becomes simpler. The number of patterns, fully explained in Study pages, decreased in relation with the previous edition. Also, tabular scheme was completely abandoned. In the entries, patterns are presented in abbreviated forms, usually in between the sense number and definition and/or before example sentence:

slam /slæm/ $v$ (-mm-) 1 to shut or make sth shut forcefully and loudly: [V,Vp, V-adj] The door slammed (to/shut). [Vn, Vn-adj] She slammed the window (shut). [Vnp] He slammed the lid down. 2 to

OALD6 verb $1[$ [adv. /prep.] to move or to move sth slowly and carefully in a particular direction: [V] She edged a little closer to me. $०$ I edged nervously past the dog. O [VN] Emily edged her chair forward. 2 [VN] [usually passive] sth (with/in sth) to put sth around the edge of sth: The handkerchief is edged with lace. $3[\mathrm{v}+a d v$. / prep.] to increase

OALD5

Figure 15. VP display in entries (OALD5, 6).

OALD7, 8 and 9 contain the simplest version of the system. Presented in a similar way as in the previous two editions, grammatical forms, in entries, are displayed as standard part-of-speech abbreviations (see Figure 16), familiar to EFL learners so that they do not have to turn the pages all the time in order to check the unknown codes and their usages in the guide.

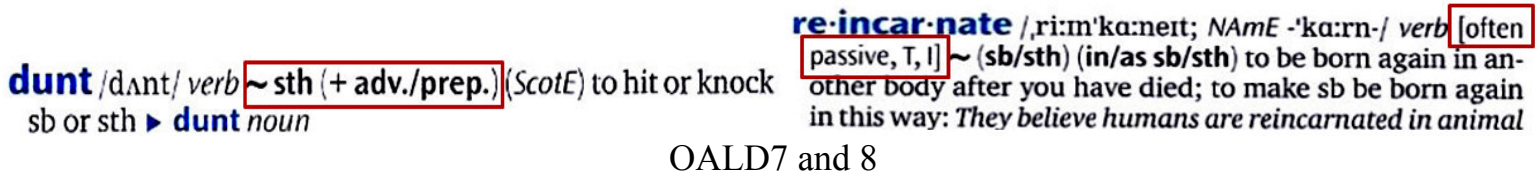

Figure 16. VP display in entries (OALD7, 8).

For most words that can be inflected in English — nouns, verbs, adjectives - the inflection follows from the general rules of morphology. However, there are some exceptions to this generalization, which all OALD's editions do record. The pattern of each irregular form is given individually, for example:

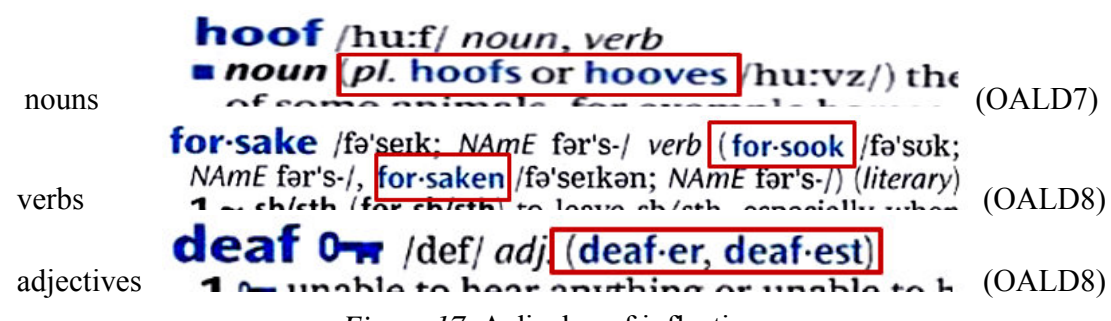

Figure 17. A display of inflections.

Senses, definitions and examples. Where a lexeme has more than one meaning, OALD marks each individual sense separately. Senses are enumerated (1, 2, 3, etc.). Definitions are made as simple as possible because OALD uses defining vocabulary - approximately 3000 words - to define all the lexemes in the dictionary. Examples in OALD, which are written in italic, are designed to meet several learning needs. They help learners understand the meanings of words, provide models for them to imitate when writing or speaking and illustrate the grammatical patterns in which words are used (OALD). Examples are of two main types: sentence examples and phrase examples. Senses, definitions and examples are presented in the same way in each OALD's edition. 

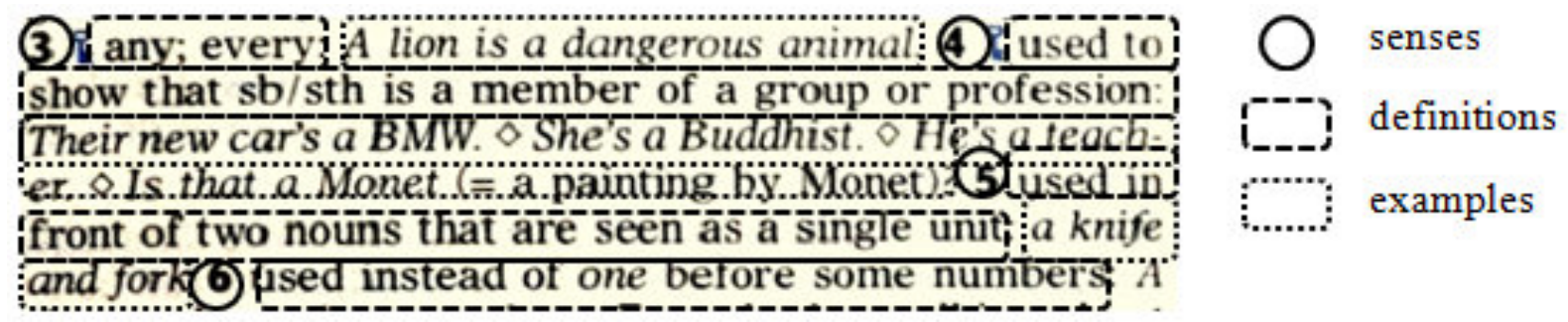

Figure 18. A fragment of an entry, labelling senses, definitions and examples (OALD9).

Usage. It is often as difficult for foreign learners to decide how to use words appropriately as it to be sure about their meanings. To help learners with these difficulties, a number of labels are used in the dictionary to denote the stylistic values of words or the technical fields in which they are used.

lac-ta-tion //lak'telfn/ $n[\mathrm{U}]$ (med, biol) production $_{\text {(OALD3) }}$

gla.ci-ation //glessı'er $\int \mathrm{n} / \boldsymbol{n}$ [U] (geology) covering with glaciers or sheets of ice: the effects of glaciation.

(OALD4)

bounteous /'bauntias/ adj [(fml or rhet $)$ giving or given generously: The earth has yielded a bounteous harvest.

(OALD5, 6)

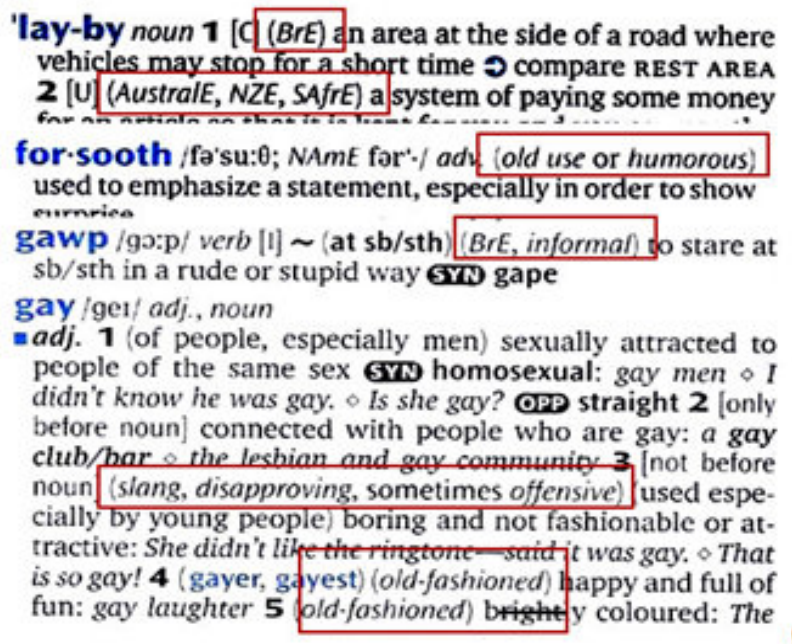

Figure 19. Usage labels (examples).

Style and field labels are of several major types - currency, region, register, evaluation, and technical field. In entries, they are printed in italics (OALD4-9) and displayed in round brackets after the grammatical information and before definition (in all editions) (see Figure 19). Usage labels are of considerable importance to EFL learners when dealing with language tasks - especially the tasks in which their encoding needs are more emphasized. The number of usage labels increased proportionally with the language learners' needs. Table 9 presents the usage labels which appear in each OALD's edition. 
Table 9

Usage Labels of OALD According to Edition

\begin{tabular}{|c|c|c|c|c|c|}
\hline & Currency & Region & Register & Evaluation & Technical field \\
\hline ISED & modern & $\begin{array}{l}\text { American, British, } \\
\text { English, French, } \\
\text { German, Greek, Great } \\
\text { Britain, Italian, } \\
\text { Japanese, Latin, } \\
\text { Russian, Scottish }\end{array}$ & rhetoric & $\begin{array}{l}\text { emphatic, figurative, } \\
\text { ironic }\end{array}$ & $\begin{array}{l}\text { literary, mathematics, military, } \\
\text { mythology, naval, poetry }\end{array}$ \\
\hline ALD2 & $\begin{array}{l}\text { archaic, } \\
\text { modern }\end{array}$ & $\begin{array}{l}\text { British, dialect, } \\
\text { English, French, } \\
\text { German, Greek, Great } \\
\text { Britain, Italian, Latin, } \\
\text { Scottish., Spanish }\end{array}$ & rhetoric, vulgar & $\begin{array}{l}\text { derogatory, emphatic, } \\
\text { euphemistic, humorous, } \\
\text { ironic, jocular }\end{array}$ & $\begin{array}{l}\text { algebra, anatomy, architecture, } \\
\text { arithmetic, botany, chemistry, } \\
\text { cinema, electricity, geology, } \\
\text { geometry, history, literary, } \\
\text { mathematics, medicine, } \\
\text { military, music, mythology, } \\
\text { nautical, naval, photography, } \\
\text { poetry, physics, science, } \\
\text { trigonometry, zoology }\end{array}$ \\
\hline OALD3 & $\begin{array}{l}\text { archaic, dated, } \\
\text { modern use, } \\
\text { old use }\end{array}$ & $\begin{array}{l}\text { French, German, } \\
\text { Great Britain, Greek, } \\
\text { Italian, Latin, Scottish, } \\
\text { United States }\end{array}$ & $\begin{array}{l}\text { formal, } \\
\text { rhetoric, slang, } \\
\text { vulgar }\end{array}$ & $\begin{array}{l}\text { derogatory, emotive, } \\
\text { emphatic, euphemistic, } \\
\text { figurative, humorous, } \\
\text { ironic, jocular, pejorative }\end{array}$ & $\begin{array}{l}\text { algebra, anatomy, architecture, } \\
\text { arithmetic, art, astronomy, }\end{array}$ \\
\hline OALD4 & archaic & $\begin{array}{l}\text { Australian, British, } \\
\text { New Zealand, } \\
\text { Scottish, United States }\end{array}$ & $\begin{array}{l}\text { formal, } \\
\text { informal, } \\
\text { rhetoric, slang, } \\
\text { vulgar }\end{array}$ & $\begin{array}{l}\text { derogatory, emphatic, } \\
\text { euphemistic, figurative, } \\
\text { jocular, taboo }\end{array}$ & $\begin{array}{l}\text { ballet, biology, book-keeping, } \\
\text { botany, business, chemistry, } \\
\text { cinema, commerce, computers, } \\
\text { cricket, engineering, electricity, }\end{array}$ \\
\hline OALD5, 6 & archaic, dated & $\begin{array}{l}\text { Australian, dialect, } \\
\text { British, New Zealand, } \\
\text { Scottish, United States }\end{array}$ & $\begin{array}{l}\text { formal, } \\
\text { informal, } \\
\text { rhetoric, slang }\end{array}$ & $\begin{array}{l}\text { approving, derogatory, } \\
\text { euphemistic, figurative, } \\
\text { ironic, jocular, offensive, } \\
\text { sexist, taboo }\end{array}$ & $\begin{array}{l}\text { farming, finance, football, } \\
\text { gambling, geology, geometry, } \\
\text { grammar, history, journalism, } \\
\text { legal, linguistics, mathematics, }\end{array}$ \\
\hline OALD7, 8,9 & $\begin{array}{l}\text { old-fashioned, } \\
\text { old use }\end{array}$ & $\begin{array}{l}\text { English: Australian, } \\
\text { British, Canadian, } \\
\text { East African, Indian, } \\
\text { Irish, North American, } \\
\text { from Northern } \\
\text { England, New } \\
\text { Zealand, South } \\
\text { African, Scottish, } \\
\text { South-East Asian, } \\
\text { from United States, } \\
\text { West African, Welsh }\end{array}$ & $\begin{array}{l}\text { formal, } \\
\text { informal, slang }\end{array}$ & $\begin{array}{l}\text { approving, disapproving, } \\
\text { figurative, humorous, } \\
\text { ironic, offensive, taboo }\end{array}$ & $\begin{array}{l}\text { mechanics, medicine, } \\
\text { meteorology, military, music, } \\
\text { mythology, nautical, pathology, } \\
\text { philosophy, phonetics, } \\
\text { photography, physics, politics, } \\
\text { psychology, racing, radio } \\
\text { telegraphy, rugby, science, } \\
\text { sport, technical, tennis, theatre, } \\
\text { trigonometry, zoology }\end{array}$ \\
\hline
\end{tabular}

With OALD's microstructure being upgraded throughout the decades, the number of usage labels increased. The first two editions included few, whereas the latest ones include many more. For instance, by the seventh edition, the category Region has been expanded by including labels referring to numerous English varieties which the previous editions lacked of. Also, the category Technical field has been greatly expanded in the third edition by the number of labels indicating scientific field which denote the context in which particular headword is used.

Other. Some microstructural elements of OALD are presented by symbols. These are:

Run-ons. Run-ons include undefined derivatives, idioms and phrasal verbs (Jackson, 2002, p. 27). In OALD, run-ons are presented in bold (italic) type after headword's definition(s) and example(s). From OALD4 onwards, these sections are marked by symbols and abbreviations ( $\triangleright$, IDM, PHR V). 


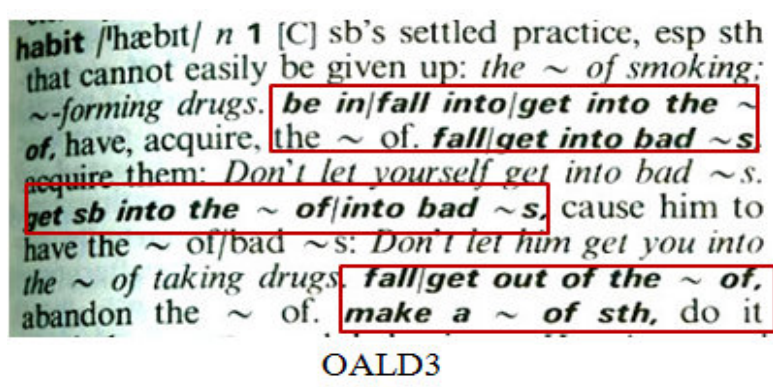

depart /dı'pa:t/ $v \sim$ (for...) (from...) (fml) to go away or leave, esp when starting a journey: [Vpr] We departed for Athens at $10 \mathrm{am}$. ० The 10.15 to Leeds departs from platform 4. [V] I thought this a fitting moment to depart. Compare ARRIVE 1. IDDM depart this 'life euph) to die [PHRV de'part from sth to behave in a way that is different from what is usual: denart from routine/tradition o depart from (ie not
[Dा give/allow sb/sth free/full 'rein | give/allow free/ full rein to sth to give-sb-emplete freedom-of action; to allow a feeling to be expressed freely: The designer was given free rein. - The script allows full rein to her largerthan-life acting style. $\rightarrow$ more at TIGHT

werb

PHRV, rein $s b / s t h \leftrightarrow$ 'back | rein $s t h \leftrightarrow$ in 1 to start to centrol-sb/sth-mere-strictly-crs-check: We need to rein back public spending. $\odot$ She kept her emotions tightly reined in. $\mathbf{2}$ to stop a horse or make it go more slowly by pulling

OALD 7,8

gaunt /go:nt/ adj. $\mathbf{1}$ (of a person) very thin, usually because of illness, not having enough food, or worry: a gaunt face $\mathbf{2}$ (of a building) not attractive and without any decoration gaunt-ness poun [U]

OALD 7, 8

\section{OALD5}

Figure 20. Run-ons display (examples).

Cross-reference. It refers to a reference from one point in the dictionary to another. Even though not used in ISED and ALD2, cross-references are widely used from OALD3, especially OALD4 onwards. They are marked by the arrow $(\hookrightarrow)$.

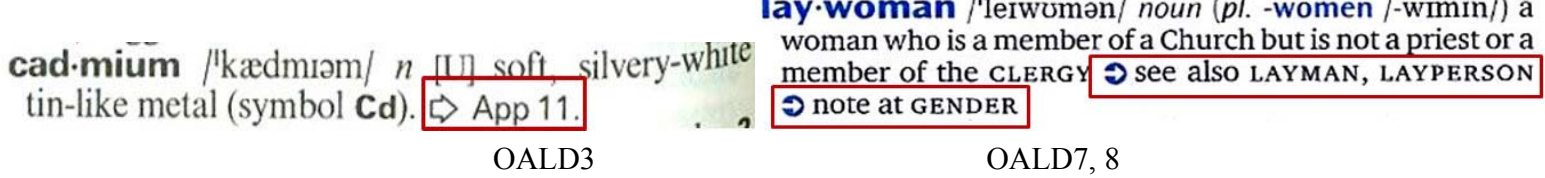

Figure 21. Cross-reference display (examples).

Synonyms and antonyms. Synonyms and antonyms sections were introduced in the seventh edition by the symbols SYN and OPP.

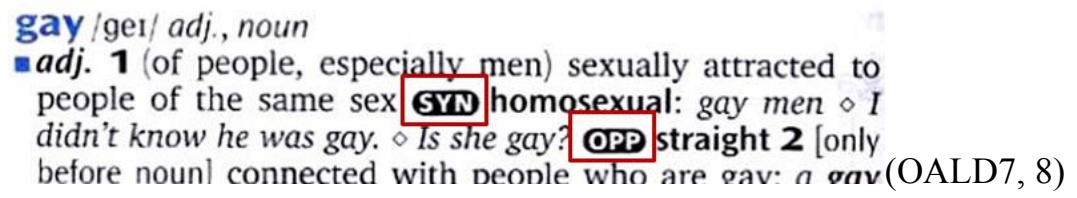

Figure 22. Synonyms and antonyms sections display (example).

Oxford 3000 and Academic Word List. OALD7 and 8 include the two sections which are presented by symbols $0-7$ (shows a word from the Oxford 3000) and (shows a word is from the Academic Word List). Also, there is a symbol TM which shows a trademark of a manufacturing company.

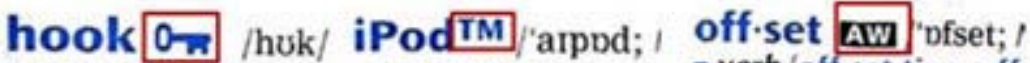 noun tom a curve ment that can stı verbloff-set-ting. off. \\ OALD $7,8,9$}

Figure 23. Oxford 3000 and Academic Word List symbols display (example).

Etymology. Even though EFL dictionaries do not contain etymological information, OALD includes it for some of the entries in the seventh and eighth editions (ORIGIN). 


\begin{abstract}
Laz·a·rus /'læzərəs/ noun used to refer to sb who improves or starts to be successful again after a period of failure OFIGIN trom the story of Lazarus in the Bible. He was a man who died but was then brought back to life by Jesus Christ.
\end{abstract}

(OALD7, 8)

Figure 24. Display of etymological information (example).

“Groups of meanings" marks. Some headwords have multiple meanings. OALD7-9 divides the groups of meanings which help users in quicker dictionary navigation. This is indicated by a symbol $D$.

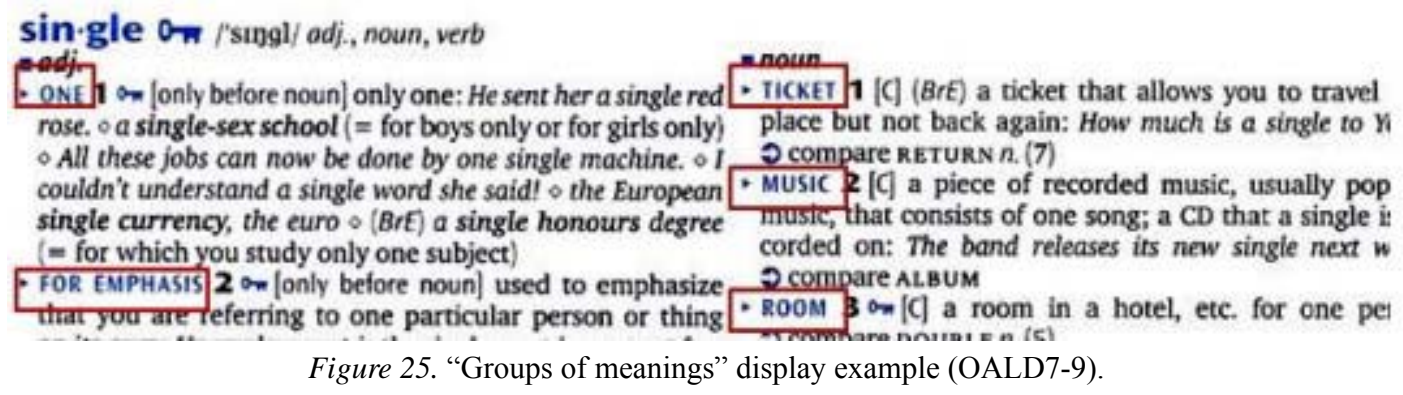

\title{
Electronic Form
}

OALD's first edition which appeared on the CD-ROM was the fifth one. It was published in 1995. Today, 22 years later, OALD is available both on DVD-ROM and on-line. When learners use OALD in its electronic form, they are able to access the full A-Z content from the latest printed dictionary. They are also able to type in a word to get quick definition, listen to the pronunciation and browse list of entries such as the Oxford 3000, the Academic word list and certain topic areas. Besides that they can use Oxford iWriter and iSpeaker guides. The Oxford iWriter guides students through the stages of planning, writing and reviewing a range of different written tasks (essays, presentations, reports, letters, reviews, CVs, etc.). There are models for each task type, showing structure, notes and sample content. Also, there is advice on choosing the right language, how to use language in order to sound more formal and more objective, or to avoid repetition. The new Oxford iSpeaker helps students in passing exams and communicating in English. With Oxford iSpeaker, they can hear individual sounds pronounced in British and American English, record themselves, listen and compare their pronunciations with the model, watch everyday conversations, studying the language used in the conversation, how to take parts in the conversation to practise using the language, watch videos of exam-style tasks, record themselves and access their speaking skills as well as practice for speaking exams (Oxford Dictionaries, n.d.).

\section{Conclusion}

Following the aims which were based both on decoding and encoding functions, OALD's structure has undergone numerous changes during its development. The macro-structural elements have been upgraded and expanded with extra contents, such as the writing and speaking tutor, extensive vocabulary builder and detailed reference section, which have greatly alleviated the processes of EFL learners' language acquisition and development of language skills. When it comes to the microstructure, OALD has been marked by the innovative and unique coded verb-pattern system which turned out to be complex and off-putting to many students, who found the constant need to refer to explanatory tables time-consuming and tiresome. In the fifth edition, the system was abandoned completely and a display of grammatical information has been simplifying 
with each new edition. Today, OALD, with all the novelties regarding dictionary's macro- and microstructure, which are primarily based on the users' increasing lexicographically relevant needs, successfully competes with all the dictionaries on the EFL market.

\section{Summary}

Throughout its chronological development, Oxford Advanced Learners' Dictionary's structure has being renewed according to increasing learners' needs. In terms of its macrostructure, a variety of new sections have been introduced, such as extensive vocabulary builder, writing and speaking tutor, etc., in order to alleviate the process of language learning. Microstructure has also been upgraded by more detailed and comprehensive, while at the same time less complex presentation of microstructural elements. This refers especially to the verb-pattern system which OALD is well-known for. Its regular advancement proves that OALD conforms to the contemporary language teaching and learning processes worldwide.

\section{References}

A. S. Hornby Educational Trust. (n.d.).Retrieved from http://www.hornby-trust.org.uk/

Cowie, A. P. (1983). EFL dictionaries: Past achievements and present needs. EURALEX '83 Proceedings, 155-163. EURALEX. Retrieved 2 Feb. 2015 from http://www.euralex.org/elx_proceedings/Euralex1983/

Cowie, A. P. (1998). A. S. Hornby-A centenary tribute. EURALEX '98 Proceedings, 3-16. EURALEX. Retrieved 10 Jan. 2015 from http://www.euralex.org/elx_proceedings/Euralex1998_1/

Cowie, A. P. (1999). English dictionaries for foreign learners-A history (pp. 1-36). New York: Oxford University Press Inc.

Cowie, A. P. (2009). The earliest foreign learners' dictionaries. In The Oxford History of English. Lexicography. (Vol. 2, pp. 385-411). Oxford: Oxford University Press.

Fuertes-Olivera, P. A., \& Tarp, S. (2011). Lexicography for the third millennium: Cognitive oriented specialized dictionaries for learners. Ibérica, 21, 141-162.

Idiomatic and syntactic English dictionary (1st ed.). (1942). The Institute for Research in Language Teaching. Tokyo, Japan: Kaitakusha.

Jackson, H. (2002). Lexicography—An introduction (pp. 21-85, 101-116, 129-144). London, New York: Routledge.

McArthur, T. (1989). The background and nature of ELT learners' dictionaries. In M. L. Tickoo (Ed.), Learners' dictionaries: State of the art (pp. 52-64). Singapore: SEAMEO Regional Language Centre.

Oxford Advanced Learner's dictionary. (2nd-9th ed.). (1963-2015). Oxford: Oxford University Press.

Oxford dictionaries. (n.d.). Oxford: Oxford University Press. Retrieved $25 \quad$ Jul. 2015 from http://www.oxforddictionaries.com/words/the-oxford-english-corpus

Stein, G. (1989). Recent developments in EFL dictionaries. In M. L. Tickoo (Ed.), Learners' dictionaries: State of the art (pp. 10-41). Singapore: SEAMEO Regional Language Centre.

The man who made dictionaries. (2015). Oxford: Oxford University Press. Retrieved 29 Jan. 2015 from http://fdslive.oup.com/www.oup.com/elt/general_content/global/man_who_made_dictionaries/

Włodarczyk-Stachurska, A. (2012). Some remarks on recent trends in lexicography. Journal of Language and Cultural Education 2(3), SlovakEdu, 120-136. 